\title{
THE DEVELOPMENT OF THE ASCIDIAN PYURA MICROCOSMUS (SAVIGNY)
}

\author{
By R. H. Millar \\ The Marine Station, Millport
}

(Text-figs. I and 2)

Several recent papers have dealt with the development of members of the ascidian family Pyuridae (Hirai, I94I ; Berrill, I948; Millar, I95I; Sebastian, 1953), but the total number of species with known larvae is still only five, in spite of the large size of the family.

The present paper deals with the embryonic development, the larva, and the post-larval development of Pyura microcosmus (Savigny).

\section{MATERIAL AND Method}

On 30 July 1953 specimens of Pyura microcosmus were collected from stones about the level of zero tides, on the north shore of Loch Creran, Argyll, on the Scottish west coast. The animals were placed in a large vacuum jar of sea water and taken on the following day to the Marine Station, Millport. Artificial fertilizations were made by mixing eggs from the oviduct of one individual with sperm from the sperm duct of another. The development obtained from three separate pairs of animals was closely similar. Shortly after fertilization the water was changed to remove excess sperm, and during the course of development two more changes of water were made. The temperature of the water varied from 18.0 to $20 \cdot 0^{\circ} \mathrm{C}$.

\section{EMBRYonic Development}

The ripe ovum is spherical and about $200 \mu$ in diameter, with pink-grey cytoplasm and a clear germinal vesicle. The ovum is surrounded by a layer of irregular outer-follicle cells, each containing a few grains of rose-purple pigment, and by scattered inner-follicle cells. The two layers of follicle cells are separated by the thin chorion which in newly extracted eggs has a diameter of about $235 \mu$. After a short time the perivitelline space enlarges and the diameter of the chorion consequently increases.

After fertilization the germinal vesicle disappears and a grey-brown cap is formed on one side of the ovum, with a pale centre and a surrounding ring of clear cytoplasm. Before the first cleavage the grey-brown cap becomes crescentic and it is shared between the first two cells during cleavage (Fig. I A). This grey-brown cytoplasm corresponds to the yellow crescent of Styela 
partita originally described by Conklin (1905), and the variously coloured crescent of other ascidians (Hirai, I94I ; Berrill, I948; Millar, I95 I; Sebastian, I953). Subsequent cleavage is essentially the same as that of styelid and pyurid ascidians already studied. The larva, still within the chorion, is fully developed and showing muscular twitchings within I $_{3}$ hours of the mixing of eggs and sperm. Hatching follows in the next few hours.

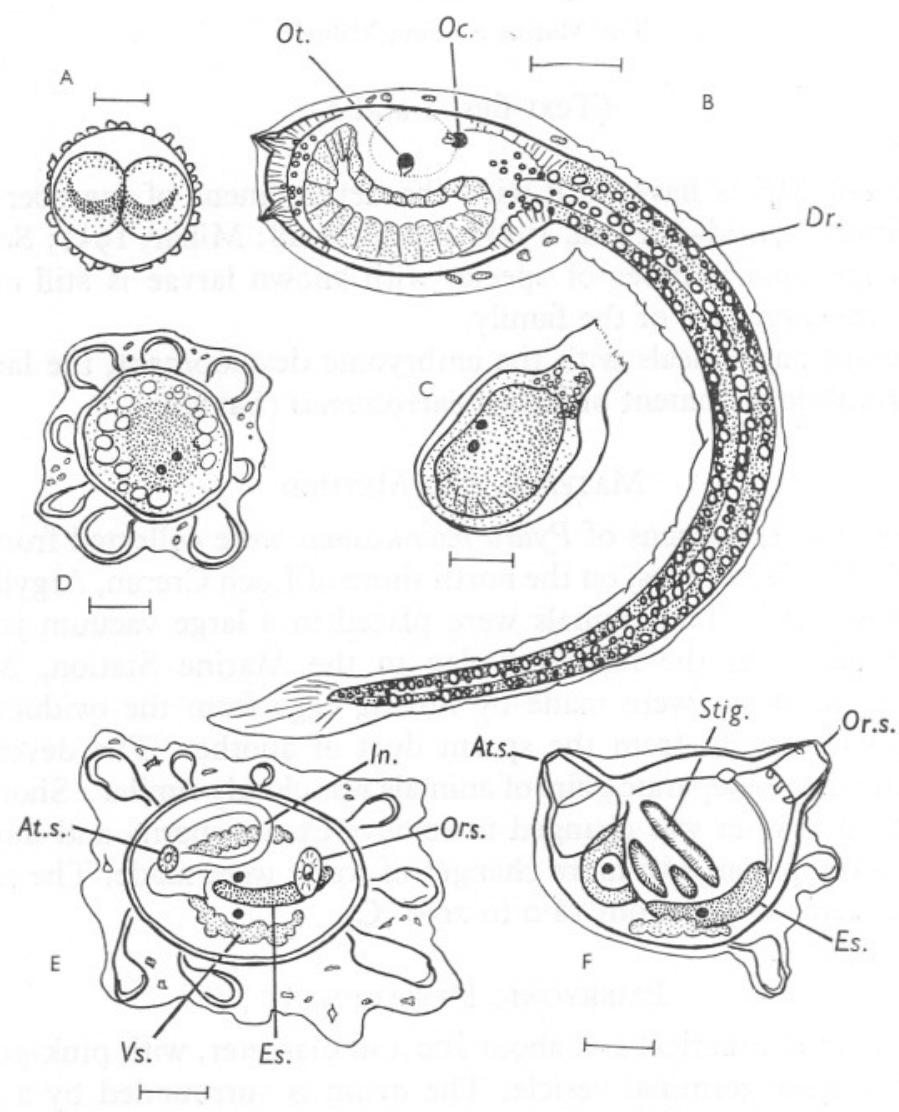

Fig. I. Development of Pyura microcosmus (Savigny). A, two-cell stage, showing dark crescent; B, larva; C, larva during metamorphosis; D, dorsal view of metamorphosing larva, with ring of ampullae; $\mathrm{E}$, dorsal view of young ascidian after differentiation of gut; $\mathrm{F}$, lateral view of young ascidian. The scales represent roo $\mu$. At.s., atrial siphon; Dr., refringent droplets; Es., endostyle; In., intestine; Oc., ocellus; Ot., otolith; Or.s., oral siphon; Stig., anterior of the first three stigmata of the branchial sac; Vs., crescent of vesicular cells.

\section{LARVA}

The larva (Fig. I B) is divided into a trunk about $285 \mu$ long, and a tail about I000 $\mu$ long. A layer of clear test covers the surface of the larva and is developed into a vertical fin along the dorsal and ventral sides of the trunk and 
tail. A leaf-like expansion of the fin projects beyond the end of the tail. At the anterior end of the trunk are two dorsal and one ventral adhesive papillae. The rudiment of the pharynx lies in the ventral half of the trunk. Near the dorsal surface of the trunk is the sensory vesicle, containing on its posterior wall the ocellus and on its ventral wall the otolith. The ocellus (Fig. I B, Oc.) has a black cup-shaped mass of pigment $14 \mu$ in diameter, behind which are the retinal cells. Clear lens cells project from the cavity of the pigment cup. The otolith (Fig. I B, Ot.) is a spherical black body I3.2 $\mu$ in diameter contained in a single pear-shaped cell which projects upwards from the floor of the sensory vesicle.

Many small refringent droplets are present in the trunk, mainly in the posterior regions; it is not certain which cells contain these droplets.

In the tail are the usual structures of the ascidian larva: a central notochord, dorsal neural strand, and three bands of striated muscle on each side. A longitudinal row of refringent droplets (Fig. I B, Dr.) is associated with each of the muscle bands of the tail.

\section{Metamorphosis and Post-Larval Development}

Within 24 hours of hatching some larvae have started to metamorphose, although others still show no sign of change. Attachment of larvae to a substratum is not necessary for metamorphosis, which occurs in attached and unattached larvae. The first change is reduction of the tissues of the tail (Fig. I C), but not the covering test which retains its original form and persists long after metamorphosis is complete. While the tail is shrinking the trunk produces a ring of anterior ampullae which are applied to the substratum (Fig. I D). Typically these ampullae number eight, but some variation is found. They grow outwards as long finger-like structures, and simultaneously a disk of expanding test spreads over the substratum. Meanwhile other changes occur in the body, and a central dark mass of cells appears, surrounded by large vesicular cells. The larval sensory pigment is still present within the body of the developing ascidian. The dark central mass now elongates and differentiates to form the rudiment of the pharynx and gut, and the surrounding vesicular cells become arranged in a crescent on each side of the pharynx. At an early stage in the formation of the pharynx the endostyle is recognizable, and shortly afterwards the oral and atrial siphons are formed (Fig. I E). The atrial siphon is, from the first, a single structure, and is not derived from the fusion of paired peribranchial openings. With the further differentiation of the gut to form the oesophagus and stomach, and the intestinal loop on the left of the pharynx, and with the perforation of one pair of protostigmata, the essential organization of the adult is accomplished. The original protostigmata divide to form two, then three, pairs of openings (Fig. IF). Up to about this stage the larval pigment of the ocellus and otolith remain unchanged within the body of the young ascidian, but now they are transported out of the body 
and deposited either on the outer surface of the test, or, more usually, quite outside the body and often at some distance from it (Fig. 2). This remarkable movement of the pigment spots, which was observed in each of the young ascidians examined, is presumably accomplished by phagocytes which, having ingested the pigment, migrate out of the body.
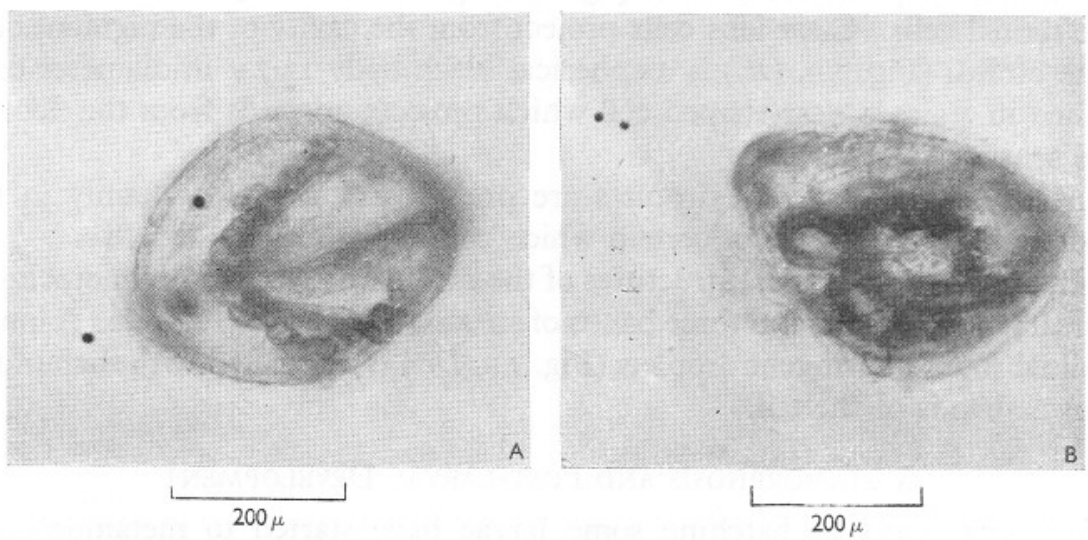

Fig. 2. Development of Pyura microcosmus (Savigny). A, dorsal view of young ascidian showing outward migration of one of the larval pigment spots. B, young ascidian after migration of both pigment spots out of the body.

The heart by now is differentiated, and starts to beat. It already shows the reversal characteristic of ascidians, although at this early stage it changes direction at irregular intervals.

Shortly after, a circle of spines develops round each of the siphons, this being the first sign of the elaboration of the test typical of the Pyuridae.

\section{Table I. Time-Table of Development}

\section{Stage}

Eggs and sperm mixed

First cleavage

Second cleavage

Gastrula

Closure of blastopore

Trunk and tail differentiated

Larva complete, and active within chorion

Larva hatched and active

Metamorphosis: tail reduced and ampullae

forming

Tail resorbed, ampullae enlarging

Endostyle differentiated

Siphons and gut differentiated

One pair of stigmata present and active

Three pairs of stigmata; removal of larval sensory pigment outside body; heart beating

Elaboration of test spines on siphons
Time

II.00 a.m., 3. viii. 53 .

I 2.20 p.m.

I2.45 p.m.

4.45 p.m.

5.45 p.m.

8.00 p.m.

Ir. 45 p.m.

9.00 a.m., 4. viii. 53 .

5. viii. 53 .

6. viii. 53

I0. viii. 53 .

II. viii. 53 .

I2. viii. 53 .

I4. viii. 53

I7. viii. 53 . 
Table I shows the times at which important stages were reached in development.

The general course and timing of development agree more closely with those of Pyura squamulosa (Alder) than with any of the other pyurid ascidians whose development has been studied. The egg of $P$. microcosmus, however, is larger than that of $P$. squamulosa, and the larva also correspondingly larger.

\section{SUMMARY}

The embryonic development, larva, and post-larval stages are described in the ascidian Pyura microcosmus (Savigny). The development is similar to that of $P$. squamulosa (Alder), but the egg and larva are larger. In the young ascidian the persisting pigment of the larval ocellus and otolith are transported out of the body, presumably by the action of phagocytes.

\section{REFERENCES}

BerRILL, N. J., I948. The nature of the ascidian tadpole, with reference to Boltenia echinata. F. Morph., Vol. 82, pp. 269-85.

Conklin, E. G., I905. The organization and cell-lineage of the ascidian egg. F. Acad. nat. Sci. Philad., Ser. 2, Vol. 13, pp. I-II9.

HiRAI, E., I94I. An outline of the development of Cynthia roretzi Drasche. Sci. Rep. Tôhoku Univ., Ser. 4, Vol. I6, No. 3, pp. 257-6r.

Millar, R. H., I95I. The development and early stages of the ascidian Pyura squamulosa (Alder). F. Mar. biol. Ass. U.K., Vol. 30, pp. 27-31.

Sebastian, V. O., I953. The development of Herdmania pallida (Heller). Proc. Indian Acad. Sci. B, Vol. 37, pp. 174-87. 